\title{
Chemical Composition and Antioxidant Activity of Walnut Pollen Samples
}

\author{
Sina COSMULESCU ${ }^{1 *}$, Ion TRANDAFIR ${ }^{2}$, Violeta NOUR ${ }^{1}$
}

\author{
'University ofCraiova, Faculty ofHorticulture,13A.I.Cuza,200585Craiova,Romania;sinacosmulescu@hotmail.com ("correspondingauthor); vionour@yahoo.com \\ ${ }^{2}$ University of Craiova, Faculty of Sciences, 13 A.I.Cuza, 200585Craiova, Romania;nehutrandafir@yahoo.com
}

\begin{abstract}
Chemical composition of pollen is highly varied depending on the plant species from which it comes and has been the subject of numerous comparative studies. The aim of this study was to determine chemical composition and antioxidant activity of walnut pollen samples and compare them with those of bee pollen. Total phenols content, total flavonoids content, antioxidant activity and mineral composition were studied using walnut pollen samples from three walnut genotypes cultivated in Romania. Total phenols content was determined by colorimetric assay and their amount varied between 10.8 and $17.64 \mathrm{mgGAE} / \mathrm{g}$ per genotype. Determination of flavonoids was done by aluminium nitrate colorimetric method and total flavonoid contents in walnut pollen ranged from 7.32 to $7.95 \mathrm{mgQE} / \mathrm{g}$. The antioxidant capacity of pollen extracts was assessed through the scavenging effects on DPPH and a concentration-dependent genotype, and it varied between 13.78 and $15.04 \mathrm{mg}$ Trolox/g. In terms of mineral composition, walnut pollen appears to be a good source of potassium $(859.14 \mathrm{mg} / 100 \mathrm{~g})$, magnesium (263.77 $\mathrm{mg} / 100 \mathrm{~g})$, calcium $(71.72 \mathrm{mg} / 100 \mathrm{~g})$, iron $(27.19 \mathrm{mg} / 100 \mathrm{~g})$, sodium $(10.52 \mathrm{mg} / 100 \mathrm{~g})$, zinc $(5.69 \mathrm{mg} / 100 \mathrm{~g})$, manganese $(3.98 \mathrm{mg} / 100 \mathrm{~g})$, copper $(1.28 \mathrm{mg} / 100 \mathrm{~g})$, chromium $(0.39 \mathrm{mg} / 100 \mathrm{~g})$ and selenium $(0.036 \mathrm{mg} / 100 \mathrm{~g})$. The results obtained indicate that walnut pollen is an important source of total phenols showing antioxidant properties and mineral composition that could be beneficial to human health.
\end{abstract}

Keywords: flavonoids, minerals, phenolics, pollen, walnut

\section{Introduction}

Pollen is the male gametophyte of flowers. Walnut (Juglans regia L.) is a monoecious plant, bearing male and female reproductive organs on separate flowers on the same tree. Walnut is a wind-pollinated species. The walnut trees produce pistillate inflorescences of one to three flowers, and staminate inflorescences (catkins), which are borne laterally on 1-year-old branches (McGranahan et al., 1994). The catkins are composed of many flowers and produce large amounts of pollen grains per inflorescence. Sutyemez (2007) has estimated the range of total pollen grain production of walnut trees to be 5-100 billion. Walnut pollen is shed in large quantities in south-western Romania during late April and early May (Cosmulescu et al., 2010). Abundancy of pollen grains per inflorescence is necessary to ensure a sufficient fruit set to the walnut. However, much of the pollen from walnut is lost. Chemical composition of pollen is highly variable depending on the plant species from which it comes and has been the subject of numerous comparative studies. Many researchers have turned their attention to the study of bee pollen. Pollen is the source of many bioactive compounds and honey bee pollen is considered to be a food. Bee pollen is composed of proteins, lipids, sugars, fibre, mineral salts, amino acids, phenolic compounds and vitamins (Margaoan et al.,
2010; Freire et al., 2012; Carpes et al., 2013; Ulusoy and Kolayli, 2014). Great variability of phenolic content was observed in the investigated species of pollen by Leja et al. (2007), and Moreira et al. (2008) indicate that Portuguese propolis is an important source of total phenols. Many studies have determined the antioxidant properties and antibacterial activity of monofloral bee pollen samples (Feas et al., 2012; Fatrcová-Šramková et al., 2013). Campos et al. (1997) believes that honey bee pollen is very important for human diets owing to a high concentration in reducing sugars, essential amino acids and unsaturated/saturated fatty acids, the presence of $\mathrm{Zn}, \mathrm{Cu}, \mathrm{Fe}$, and high $\mathrm{K} / \mathrm{Na}$ ratio. The Chinese bee pollen was evaluated as a good complement to diet by Yang et al. (2013). Some mineral elements have already been quantified in bee pollen samples from several countries: potassium, phosphorus, magnesium, calcium, sodium, sulphur, iron, copper, manganese, zinc, chromium, nickel and selenium (Orzaez Villanueva et al., 2001; Margaoan et al., 2010; Morgano et al., 2012). High levels of beneficial elements such as potassium, calcium, manganese, zinc, iron, magnesium and copper were observed in pollen samples by Yang et al. (2013).

It is recognized that pollen is a potentially valuable apitherapy medicine, with health and nutritional applications. Additionally, pollen and catkins are considered by-products in walnut plantations. For these reasons and considering the large amount 
362

of pollen that walnut produces, the objective of this study was to determine chemical properties of walnut pollen samples (total phenols content, total flavonoid content, antioxidant activity and mineral content) and compare them with those of bee pollen.

\section{Materials and Methods}

\section{Samples}

Three different pollen samples were hand collected from inflorescences of three walnut genotypes. Genotypes were provided from the same region (south-western Romania), grown under the same conditions. Pollen was harvested during the flowering of catkins and subjected to natural drying process (at room temperature).

The methanolic pollen extracts used for determining the contents of total phenolic compounds, total flavonoids and antioxidant activity were prepared by extracting one gram of pollen in $10 \mathrm{~mL}$ methanol in an ultrasonic bath for $60 \mathrm{~min}$. Extraction was continued at room temperature for 24 hours. Then the samples were centrifuged and the supernatants were then filtered through $0.45-\mu \mathrm{m}$ filter and stored at $4{ }^{\circ} \mathrm{C}$ until analysis.

\section{Chemicals and Reagents}

Folin-Ciocalteu reagent (2N, Sigma-Aldrich), gallic acid (Sigma-Aldrich), anhydrous sodium carbonate (Sigma-Aldrich), methanol (Merck), 2,2-diphenyl-1-picrylhydrazyl (DPPH; Merck), ascorbic acid (Merck), quercetin (Merck), aluminium nitrate (Sigma-Aldrich), potassium acetate (Sigma-Aldrich) were used in this experiment.

\section{Determination of totalphenolic content}

Total phenolics content in the extracts was determined calorimetrically with Folin-Ciocalteu reagent by using the method described by Cosmulescu et al. (2015a). $5 \mathrm{~mL}$ Folin-Ciocalteu reagent (diluted 1:5 with ultrapure water) were added to $1 \mathrm{~mL}$ extract (diluted 1:20 with methanol) and stirred for one minute After $2 \mathrm{~min}, 4 \mathrm{~mL}$ of $7.5 \%$ sodium carbonate solution were added and they were kept in the incubator during $2 \mathrm{~h}$ at the room temperature. The absorbance of mixture was measured at $765 \mathrm{~nm}$ using an Evolution 600 UV/VIS spectrophotometer (Thermo Scientific, USA). Gallic acid was used to prepare the standard curve $(0-250 \mathrm{mg} / \mathrm{L})$ and the results were expressed as gallic acid equivalents in milligrams per gram (mg GAE/g).

\section{Totalflavonoids content}

Determination of flavonoids was done by aluminium nitrate colorimetric method described by Cosmulescu et al. (2015a). Briefly, $0.5 \mathrm{~mL}$ of extract was diluted with methanol and mixed in a test tube with $0.1 \mathrm{~mL}$ of $10 \%$ aluminium nitrate, $0.1 \mathrm{~mL}$ of $1 \mathrm{M}$ aqueous potassium acetate and $4.3 \mathrm{~mL}$ methanol. After keeping for $40 \mathrm{~min}$ at room temperature, the absorbance of reaction mixture was measured at $415 \mathrm{~nm}$. Quercetin was used for preparing the standard curve $(0-100 \mathrm{mg} / \mathrm{L})$. The results were expressed as milligrams of quercetin equivalents per gram ( $\mathrm{mg}$ $\mathrm{QE} / \mathrm{g})$

\section{Antioxidant activity}

The capacity of scavenging of the 2,2-diphenyl-1picrylhydrazyl (DPPH) free radical was monitored according to the method reported by Cosmulescu et al. (2015a). Briefly, 50 $\mu \mathrm{L}$ of sample extracts were mixed with $3 \mathrm{~mL}$ of methanolic solution containing DPPH radicals $(40 \mathrm{mg} / \mathrm{L})$. The mixture was kept in dark for 30 minutes, and the absorbance was measured at $517 \mathrm{~nm}$. All assays were conducted in triplicate. Antioxidant capacity was expressed in $\mathrm{mg}$ Trolox equivalents per gram (mg Trolox $/ g)$.

\section{Determination of mineral and trace elements content}

Potassium $(\mathrm{K})$, calcium $(\mathrm{Ca})$, magnesium $(\mathrm{Mg})$, sodium $(\mathrm{Na})$, iron $(\mathrm{Fe})$, manganese $(\mathrm{Mn})$, copper $(\mathrm{Cu})$, zinc $(\mathrm{Zn})$, selenium ( $\mathrm{Se}$ ) and chromium $(\mathrm{Cr})$ were determined by microwave digestion followed by inductively coupled plasma mass spectrometry (ICP-MS) analysis according to the method previously described by Cosmulescu et al. (2015b). Briefly, samples of approximately $0.4 \mathrm{~g}$ pollen were weighed in the digestion bottle, over which $5 \mathrm{~mL}$ of $65 \%$ nitric acid and $2 \mathrm{~mL}$ of $30 \%$ hydrogen peroxide were added. Digestion was performed at $180^{\circ} \mathrm{C}$ for $20 \mathrm{~min}$ in the Milestone digestion microwave system. After the digestion was completed, the content solution was transferred into a $50 \mathrm{~mL}$ volumetric flask and made up to the mark with ultrapure water. The sample solutions were stored in polyethylene vials at $6^{\circ} \mathrm{C}$ until analysis. Quantification of mineral elements was performed by ICP MS Elan 9000 (Perkin Elmer Sciex, Canada) equipped with Meinhard nebulizer, and Scotttype double-pass spray chamber was used throughout. Calibration standards were prepared for all 10 elements by appropiate dillution from $1000 \mu \mathrm{g} / \mathrm{mL}$ pure single-element standard solutions (PerkinElmer, Shelton, CT) and linear calibration curves were established for concentration vs. absorbance. The results were expressed in $\mathrm{mg} / 100 \mathrm{~g}$.

\section{Statistical analysis}

Data were subjected to analysis of variance (ANOVA) using Statgraphics Centurion XVI software (StatPoint Technologies, Warrenton, VA, USA). Differences were estimated with a multiple range test using the least significant difference (LSD) at $\mathrm{P}<0.05$.

\section{Results and Discussion}

\section{Total phenolics, total flavonoid content and antioxidant activity}

The three pollen samples were studied in terms of chemical properties: total phenols content, total flavonoid content and antioxidant activity. The total phenols content, total flavonoid content and antioxidant activity of the pollen samples are given in Table 1. The results indicated significant differences between the samples analyzed $(\mathrm{P}<0.05)$. Phenol contents of pollen samples 1 and 3 had higher values than sample 2 , while total phenol contents of walnut pollens ranged between $10.8-17.64 \mathrm{mg}$ GAE/g pollen. Comparatively, Ulusoy and Kolayli (2014) found a total phenol content of Anzer pollens from beekeepers that varied between 44.07 and $124.10 \mathrm{mg} \mathrm{GAE} / \mathrm{g}$. In sample of monofloral bee pollen the polyphenol content was within the range from 319.31 to $1383.67 \mathrm{mg} / \mathrm{kg}$ (Fatrcová-Sramková et al., 2013). The contents of phenolic compounds of bee pollen produced in the Southern region of Brazil were $30.46 \mathrm{mg} \mathrm{GAE} / \mathrm{g}$ (Carpes et al., 2009). It is found that, due to diversity and complexity of bee pollen, polyphenol content has varied from one area to another and sometimes more than the results obtained in walnut pollen in this study. 
Total flavonoid contents in walnut pollen, expressed in $\mathrm{mg}$ QE/g, ranged from 7.32 to $7.95 \mathrm{mg} / \mathrm{g}$ of pollen (Table 1 ). Comparatively, flavonoid content in tea pollen extracts ranged from 1.94 to $8.12 \mathrm{mg} \mathrm{QE} / \mathrm{g}$ (Kao et al., 2011). In the bee pollen, Carpes et al. (2009) reported an average total flavonoids of $8.92 \mathrm{mg}$ QE/g. Depending on the species and beebread, Stanciu et al. (2011) reported a flavonol and flavones content of bee pollens between 0.224 (Rosa canina) and $1.008 \mathrm{mg} \mathrm{QE} / \mathrm{g}$ (mixture of bee pollen from Brassica napus and Taraxacum officinale). Also, the amounts of flavonols and flavones, were determined by LeBlanc $e t$ al. (2009) in terms of mg QE/g of bee pollen Sonoran Desert sample, obtaining values between 5.48 and $2.66 \mathrm{mg} \mathrm{QE} / \mathrm{g}$. Analysis performed on organic bee pollen by Feas et al. (2012) showed that phenolic and flavonoid contents varied from 12.9 to $19.8 \mathrm{mg}$ of gallic acid equivalents/g of extract and from 4.5 to 7.1 $\mathrm{mg}$ of catechin equivalents/g of extract, respectively. In terms of content of flavonoids, the results obtained by other researchers are different, depending on the area of study, pollen composition and material analyzed. It was found that walnut pollen, which showed higher levels of phenolic compounds, has a high level of flavonoids.

The pollen methanolic extracts contained higher amounts of total polyphenols and flavonoids, and were consistent with the higher total antioxidant activity obtained in the study. In terms of antioxidant activity, results are presented in Table 1 , and ranged from 13.87 to $15.04 \mathrm{mg}$ Trolox/g pollen. Comparatively, the DPPH values of methanol extracts of the 12 monofloral bee pollens, reported by Marghitas et al. (2009), ranged from 0.135 (bee pollen from Pinus sp.) to $2.814 \mathrm{mmol}$ Trolox/g DM (bee pollen from Salixsp.).

Table 1. Total phenolics, flavonoid and antioxidant activity of walnut pollen samples $(\mathrm{mg} / \mathrm{g})$

\begin{tabular}{|c|c|c|c|}
\hline Samples & $\begin{array}{c}\text { Total phenolics } \\
\text { content }^{*}\end{array}$ & $\begin{array}{c}\text { Total flavonoid } \\
\text { content }^{* *}\end{array}$ & $\begin{array}{l}\text { Antioxidant } \\
\text { capacity }^{* * *}\end{array}$ \\
\hline Samples 1 & $17.64 \pm 0.89^{b}$ & $7.77 \pm 0.38^{\mathrm{ab}}$ & $13.87^{\mathrm{a}}$ \\
\hline Samples 2 & $10.80 \pm 0.61^{\mathrm{a}}$ & $7.32 \pm 0.25^{a}$ & $14.91^{\mathrm{a}}$ \\
\hline Samples 3 & $16.32 \pm 0.77^{b}$ & $7.95 \pm 0.21^{b}$ & $15.04^{\mathrm{a}}$ \\
\hline \multicolumn{4}{|c|}{$\begin{array}{l}\text { Data expressed as means } \pm S E \text { of three samples analyzed separately: } \\
\text { * gallic acid equivalents; } \\
\text { ** quercetin equivalents; } \\
\text { ***Trolox equivalents. } \\
\text { Different superscript letters within the same column indicate significa } \\
\text { differences }(P<0.05) \text { among samples }\end{array}$} \\
\hline
\end{tabular}

Table 2. Mineral composition (mg/100g DW) of walnut pollen samples*

\begin{tabular}{|c|c|c|c|c|c|}
\hline \multirow{2}{*}{ Minerals } & \multicolumn{3}{|c|}{ Samples } & \multirow{2}{*}{ Mean } & \multirow{2}{*}{$\begin{array}{c}\text { Percentage expressed as } \\
\text { total minerals (\%) }\end{array}$} \\
\hline & 1 & 2 & 3 & & \\
\hline $\mathrm{Mn}$ & $3.11 \pm 0.18^{\mathrm{a}}$ & $3.78 \pm 0.24^{\mathrm{b}}$ & $5.05 \pm 0.37^{c}$ & 3.98 & 0.32 \\
\hline $\mathrm{Zn}$ & $5.34 \pm 0.41^{a}$ & $5.57 \pm 0.35^{a}$ & $6.18 \pm 0.55^{a}$ & 5.69 & 0.46 \\
\hline Se & $0.04 \pm 0.01^{\mathrm{a}}$ & $0.03 \pm 0.01^{\mathrm{a}}$ & $0.04 \pm 0.01^{\mathrm{a}}$ & 0.036 & 0.00 \\
\hline $\mathrm{Ca}$ & $43.71 \pm 1.88^{a}$ & $47.73 \pm 2.54^{a}$ & $123.74 \pm 5.79^{b}$ & 71.72 & 5.77 \\
\hline $\mathrm{Cr}$ & $0.28 \pm 0.02^{\mathrm{a}}$ & $0.42 \pm 0.03^{\mathrm{b}}$ & $0.47 \pm 0.03^{b}$ & 0.39 & 0.03 \\
\hline $\mathrm{Cu}$ & $1.26 \pm 0.08^{b}$ & $1.03 \pm 0.07^{\mathrm{a}}$ & $1.56 \pm 0.09^{c}$ & 1.28 & 0.10 \\
\hline $\mathrm{Fe}$ & $11.24 \pm 0.77^{\mathrm{a}}$ & $13.88 \pm 0.92^{\mathrm{a}}$ & $56.46 \pm 2.45^{b}$ & 27.19 & 2.19 \\
\hline $\mathrm{Mg}$ & $295.65 \pm 16.58^{b}$ & $254.48 \pm 13.88^{a}$ & $241.20 \pm 13.41^{\mathrm{a}}$ & 263.77 & 21.21 \\
\hline $\mathrm{Na}$ & $2.04 \pm 0.17^{\mathrm{a}}$ & $3.88 \pm 0.23^{b}$ & $25.64 \pm 1.22^{c}$ & 10.52 & 0.85 \\
\hline \multirow[t]{2}{*}{ K } & $776.57 \pm 36.66^{a}$ & $698.35 \pm 28.75^{a}$ & $1102.5 \pm 52.59^{b}$ & 859.14 & 69.08 \\
\hline & \multicolumn{3}{|c|}{ Total minerals } & 1243.71 & \\
\hline
\end{tabular}

${ }^{*}$ Data expressed as means \pm SE of three samples analyzed separately.

Different superscript letters within the same row indicate significant differences $(\mathrm{P}<0.05)$ among samples

\section{Mineral content}

The predominant minerals in the pollen samples were potassium $(859.14 \mathrm{mg} / 100 \mathrm{~g})$, followed by magnesium $(263.77$ $\mathrm{mg} / 100 \mathrm{~g})$, calcium $(71.72 \mathrm{mg} / 100 \mathrm{~g})$ and iron $(27.19 \mathrm{mg} / 100 \mathrm{~g})$. Statistical analysis demonstrated significant difference in minerals in the walnut pollen samples $(\mathrm{P}<0.05)$ (Table 2). Regardless of samples, potassium occurred at the highest concentrations in all tested pollen samples. It accounted for as much as $69 \%$ of total content of minerals determined in the samples. The second largest with respect to content level was magnesium (21\%) followed by calcium (5.77\%) and iron (2.19\%). Manganese, zinc, selenium, chromium, copper and sodium accounted jointly for about $1.76 \%$ of total content of minerals in the tested pollen samples. The order of nutritive elements, depending on their content $(\mathrm{mg} / 100 \mathrm{~g})$ of pollen, was: $\mathrm{K}>\mathrm{Mg}>\mathrm{Ca}>\mathrm{Fe}>\mathrm{Na}>\mathrm{Zn}>\mathrm{Mn}>\mathrm{Cu}>\mathrm{Cr}>\mathrm{Se}$. On mineral content in commercially pollen, Orzaez Villanueva et al. (2001) shows that potassium has the highest concentration in the natural product, with values above $400 \mathrm{mg} / 100 \mathrm{~g}$, followed by iron and zinc, with different results, depending on the brand sold, with mean values of 4.01 and $3.66 \mathrm{mg} / 100 \mathrm{~g}$, respectively. The average potassium content $(859.14 \mathrm{mg} / 100 \mathrm{~g})$ in pollen walnut determined in this study was higher than those reported by Orzaez Villanueva et al. (2001) for commercial pollen of Spain (400 $\mathrm{mg} / 100 \mathrm{~g}$ ) and similar to that reported by Stanciu et al. (2011) in the pollen of Helianthus annuus $(5902.76 \mathrm{mg} / \mathrm{kg}$ ) and Salix sp. $(8686.64 \mathrm{mg} / \mathrm{kg})$ flower. Significant difference $(\mathrm{p}<0.05)$ was found between walnut pollen samples with respect to the magnesium content (Table 2).

In this study, magnesium content was higher $(263.77 \mathrm{mg} / 100$ g) than that reported by Stanciu et al. (2011) for Salix sp. pollen $(2193.13 \mathrm{mg} / \mathrm{kg})$. Higher levels of magnesium were determined in flower pollen of Helianthus annuus and Salis sp. by Stanciu et al. (2011). Results in this study indicate that magnesium values in walnut pollen are higher than those reported by Szczesna (2007) for multifloral pollen samples originating harvested from China $(441 \mathrm{mg} / \mathrm{kg}$ ) and South Korea $(430 \mathrm{mg} / \mathrm{kg}$ ) and similar Poland samples $(762 \mathrm{mg} / \mathrm{kg})$. Walnut pollen contained also the highest calcium content $(71.72 \mathrm{mg} / 100 \mathrm{~g})$. The determined calcium levels in honeybee-collected pollen reported by Stanciu et al. (2011) showed a high variability, ranged between 824.38-1328.04 mg $\mathrm{Ca} / \mathrm{kg}$. Iron content $(27.19 \mathrm{mg} / 100 \mathrm{~g})$ was lower than the one reported by Szczesna (2007) with variation within $11.24 \mathrm{mg} / 100$ $\mathrm{g}$ and $56.46 \mathrm{mg} / 100 \mathrm{~g}$. In comparison, the results of this study are pollen samples $(325.29 \mathrm{mg} / \mathrm{kg})$. similar to those obtained by Stanciu et al. (2011) from Salix sp. 
Table 3. Recommended dietary allowances (RDA) or adequate intake (AI) level of a nutrient ${ }^{*}$

\begin{tabular}{|c|c|c|c|c|}
\hline \multirow[b]{2}{*}{ Nutrient } & \multicolumn{2}{|c|}{ Recommended Dietary Allowances } & \multirow{2}{*}{$\begin{array}{l}\text { Average content in } \\
\text { walnut pollen } \\
(\mathrm{mg} / 100 \mathrm{~g} D W)\end{array}$} & \multirow{2}{*}{$\begin{array}{c}\text { \% of RDI } \\
\text { (100 g walnut } \\
\text { pollen) }\end{array}$} \\
\hline & Unit & RDA/AI & & \\
\hline Potassium, K & $\mathrm{mg}$ & 4700 & 859.14 & 18.27 \\
\hline Magnesium, $\mathrm{Mg}$ & $\mathrm{mg}$ & 400 & 263.77 & 65.94 \\
\hline Calcium, Ca & $\mathrm{mg}$ & 1000 & 71.72 & 7.17 \\
\hline Iron, $\mathrm{Fe}$ & $\mathrm{mg}$ & 8 & 27.19 & 339.87 \\
\hline Sodium, $\mathrm{Na}$ & $\mathrm{mg}$ & 1500 & 10.52 & 0.70 \\
\hline Zinc, Zn & $\mathrm{mg}$ & 11 & 5.69 & 51.72 \\
\hline Manganese, Mn & $\mathrm{mg}$ & 2.3 & 3.98 & 173.04 \\
\hline Copper, $\mathrm{Cu}$ & $\mu \mathrm{g}$ & 900 & 1.28 & 142.22 \\
\hline Chromium, Cr & $\mu \mathrm{g}$ & 35 & 0.39 & 1114.28 \\
\hline Selenium, Se & $\mu \mathrm{g}$ & 55 & 0.036 & 65.45 \\
\hline
\end{tabular}

*Source: http://en.wikipedia.org/wiki/Dietary_Reference_Intake\#Vitamins_and_minerals

In the present study the sodium mean content is 10.52 $\mathrm{mg} / 100 \mathrm{~g}$ with variation range from 2.04 to $25.64 \mathrm{mg} / 100 \mathrm{~g}$, values that are similar to those reported by Szczesna (2007) for multifloral bee pollen harvested from Poland, China and South Korea $(65.4,108.2$ and $176.7 \mathrm{mg} / \mathrm{kg}$, respectively). The mean zinc content was $5.69 \mathrm{mg} / 100 \mathrm{~g}$ and there are significant differences between samples. Similar results were reported by Carpes et al. (2009) in pollen samples from Southern Brazil $(50.63 \mathrm{mg} / \mathrm{kg})$. The walnut pollen analyzed has a good content of manganese (mean $3.98 \mathrm{mg} / 100 \mathrm{~g}$ ); the values were between 3.11 and 5.05 $\mathrm{mg} / 100 \mathrm{~g}$. Manganese content is higher than the one reported by Szczesna (2007) in multifloral bee pollen from Poland (mean 26.3 $\mathrm{mg} / \mathrm{kg})$. Copper levels in the present study $(1.03-1.56 \mathrm{mg} / 100 \mathrm{~g}$; mean $1.28 \mathrm{mg} / 100 \mathrm{~g}$ ) tend to be higher than those of Brazilian bee pollen samples (mean $9.6 \mathrm{mg} / \mathrm{kg}$ ), but in agreement with those found in South Korean $(10.1 \mathrm{mg} / \mathrm{kg})$ multifloral pollen samples. In walnut pollen samples the chromium and selenium levels ranged from 0.28 to 0.47 and 0.03 to $0.04 \mathrm{mg} / 100 \mathrm{~g}$, respectively. In general the mineral contents are comparable to the values observed in the bee pollen. However for potassium, calcium and magnesium, walnut pollen appears to be a better source of these elements.

Table 3 is based on the Recommended Dietary Allowances (RDA), and highlights the nutritional value of walnut pollen. With regard to nutritional aspects, the $100 \mathrm{~g}$ of walnut pollen can meet or exceed the RDA of $\mathrm{Fe}, \mathrm{Mn}, \mathrm{Cu}$ and $\mathrm{Cr}$. This amount of walnut pollen can also provide a reasonable amount (51.72 65.94\%) of $\mathrm{Zn}, \mathrm{Se}$ and $\mathrm{Mg}$. The contribution of $\mathrm{K}, \mathrm{Ca}$, and $\mathrm{Na}$ is low $(18.27 \%, 7.17 \%, 0.70 \%$, respectively).

In conclusion, the data obtained in this study do confirm that walnut pollen represents a valuable source of different nutrients and that mineral composition varies by genotype. The methanolic pollen extracts showed diverse antioxidant activities. The results indicated that walnut pollen could be a good source of dietary minerals and antioxidants.

\section{Acknowledgments}

This work was partially supported by the grant number $11 \mathrm{C} / 2014$, awarded in the internal grant competition of the University of Craiova, Romania.

\section{References}

Campos MG, Markham K, Cunha A (1997). Bee-pollen: composition, properties and applications. In: Mizrahi A (Ed). Bee Products. Plenum Publishing Company, London pp 93-100.
Carpes ST, De Alencar SM, Cabral IS, Oldoni TLC, Mourao GB, Haminiuk CWI, Masson ML (2013). Polyphenols and palynological origin of bee pollen of Apis mellifera L. from Brazil. Characterization of polyphenols of bee pollen. CyTA-Journal of Food 11:150-161.

Carpes ST, Mourão GB, De Alencar SM, Masson ML (2009). Chemical composition and free radical scavenging activity of Apis mellifera bee pollen from Southern Brazil. Brazilian Journal of Food Technology 12:220-229.

Cosmulescu S, Baciu A, Botu M, Achim G (2010). Environmental factors' influence on walnut flowering. Acta Horticulturae 861:83-88.

Cosmulescu S, Trandafir I, Nour V, Botu M (2015a). Total phenolic, flavonoid distribution and antioxidant capacity in skin, pulp and fruit extracts of plum cultivars. Journal of Food Biochemistry 39:64-69.

CosmulescuS, Trandafir I, Nour V(2015b). Mineral composition of fruit in black and red currant. South Western Journal of Horticulture, Biology andEnvironment 6:43-51.

Fatrcová-Šramková K, Nôžková J, Kačániová M, Máriássyová M, Rovná K, Stričík M (2013). Antioxidant and antimicrobial properties of monofloral bee pollen. Journal of Environmental Science and Health, Part B48:133-138.

Feas X, Vazquez-Tato MP,Estevinho L, Seijas JA, Iglesias A (2012). Organic bee pollen: botanical origin, nutritional value, bioactive compounds, antioxidant activity and microbiological quality. Molecules 17:83598377.

Freire KR, Lins A, Dórea MC, Santos FA, Camara CA, Silva T (2012). Palynological origin, phenolic content and antioxidant properties of honeybee-collected pollen from Bahia, Brazil. Molecules 17:1652-1664.

Kao YT, Lu MJ, Chen C (2011). Preliminary analyses of phenolic compounds and antioxidant activities in tea pollen extracts. Journal of FoodandDrug Analysis 19:470-477.

Leblanc BW, Davis OK, Boue S, Delucca A, Deeby T (2009). Antioxidant activity ofSonoran Desert bee pollen. Food Chemistry 115:1299-1305.

Leja M, Mareczek A, Wyżgolik G, Klepacz-Baniak J, Czekońska K (2007). Antioxidative properties of bee pollen in selected plant species. Food Chemistry 100:237-240.

Margaoan R, Marghitas L, Dezmirean D, Mihai C, Bobis O (2010). Bee collected pollen. General aspects and chemical composition. Bulletin of University of Agricultural Sciences and Veterinary Medicine Cluj Napoca. Animal Science and Biotechnologies 67:254259.

Marghitas LA, Stanciu OG, Dezmirean DS, Bobis O, Popescu O, Bogdanov S, Campos MG (2009). In vitro antioxidant capacity of honeybee- 
collected pollen of selected floral origin harvested from Romania. Food Chemistry 115:878-883.

McGranahan GH, Voyiatzis DG, Catlin PB, Polito VS (1994). High pollen loads can cause pistillate flower abscission in walnut. Journal of the American Society for Horticultural Science 119:505-509.

Moreira L, Dias LG, Pereira JA, Estevinho L (2008). Antioxidant properties, total phenols and pollen analysis of propolis samples from Portugal. Food and Chemical Toxicology 46:3482-3485.

Morgano MA, Martins MCT, Rabonato LC, Milani RF, Yotsuyanagi K, Rodriguez-Amaya DB (2012). A comprehensive investigation of the mineral composition of Brazilian bee pollen: geographic and seasonal variations and contribution to human diet. Journal of the Brazilian Chemical Society 23:727-736.

Orzaez Villanueva A, Diaz Marquina R, Bravo Serrano G, Blazquez Abellan MT (2001). Mineral content of commercial pollen. International Journal of Food Sciences and Nutrition 52:243-249.
Stanciu OG, Marghitas LA, Dezmirean D, Campos MG (2011). A comparison between the mineral content of flower and honeybee collected pollen of selected plant origin (Helianthus annuus L. and Salix sp.). Romanian Biotechnological Letters 16:6291-6296.

Sutyemez M (2007). Determination of pollen production and quality of some local and foreign walnut genotypes in Turkey. Turkish Journal of Agriculture and Forestry 31:109-114.

Szczesna T (2007). Concentration of selected elements in honeybeecollected pollen. Journal of Apicultural Science 51:5-13.

Ulusoy E, Kolayli S (2014). Phenolic composition and antioxidant properties of Anzer bee pollen. Journal of Food Biochemistry 38:73-82.

Yang K, Wu D, Ye X, Liu D, Chen J, Sun P (2013). Characterization of chemical composition of bee pollen in China. Journal of Agricultural and Food Chemistry 61:708-718. 